\title{
INVESTIGATION OF CHROME-GREASING DIFFUSION INTO THE SHEEPSKIN STRUCTURE
}

\section{INVESTIGAREA DIFUZIEI AGENTULUI DE UNGERE ŞI CROMARE ÎN STRUCTURA PIELII DE OAIE CU BLANĂ}

\author{
Dmitry SHALBUEV*, Yulia KALASHNIKOVA, Sergey POLOMOSHNIKH, Elena LEONOVA
}

East Siberia State University of Technology and Management, 40 V Kluchevskaya St., Ulan-Ude, 670013, shalbuevd@mail.ru

\section{INVESTIGATION OF CHROME-GREASING DIFFUSION INTO THE SHEEPSKIN STRUCTURE}

ABSTRACT. The authors have studied chrome-greasing fluid diffusion into the sheepskin structure by scanning electron microscopy. The results confirm the even distribution of chrome tanning components in the structure of semi-processed sheepskin during ageing for 2 hours. The quality of the finished product, produced according to the innovative technology of combined tanning and greasing with integrated mechanical processing, mees the regulatory requirements of TRCU 017/2011 "On the safety of products of light industry". The proposed innovative method of tanning and greasing fluid diffusion into sheepskin structure can significantly reduce processing time of semi-finished sheepskin from 4 hours to 4.5 minutes, ageing time from 4 to 2 hours and considerably reduce water consumption and, thus, decrease toxic effluents emission containing trivalent chromium.

KEY WORDS: tanning and greasing, chrome-greasing emulsion, leather, diffusion, scanning electron microscopy

\section{INVESTIGAREA DIFUZIEI AGENTULUI DE UNGERE ŞI CROMARE ÎN STRUCTURA PIELII DE OAIE CU BLANĂ}

ABSTRACT. Autorii au studiat difuzia în structura pielii de oaie a unui amestec de săruri de crom şi agent de ungere prin microscopie electronică de baleiaj. Rezultatele au confirmat distribuţia omogenă a compuşilor tananţi cu crom în structura semi-fabricatelor de piele de oaie în perioada de odihnă de 2 ore. Calitatea produsului finit, realizat în conformitate cu tehnologia inovatoare combinată de tăbăcire şi ungere cu prelucrare mecanică integrată, îndeplineşte cerinţele de reglementare ale TRCU 017/2011, „Siguranţa produselor din industria uşoară". Metoda inovatoare propusă, de tăbăcire şi ungere prin difuzia fluidului în structura pielii de oaie, poate reduce semnificativ timpul de prelucrare a semifabricatelor de piele de oaie de la 4 ore la 4,5 minute, timpul de odihnă de la 4 la 2 ore şi poate reduce considerabil consumul de apă, reducând, prin urmare, şi emisiile de efluenţi toxici cu conţinut de crom trivalent.

CUVINTE CHEIE: tăbăcire şi ungere, emulsie de ungere cu crom, piele, difuzie, microscopie electronică de baleiaj

\section{L'INVESTIGATION DE LA DIFFUSION DE L'AGENT LUBRIFIANT ET DE CHROMAGE DANS LA STRUCTURE DE LA FOURRURE DE MOUTON}

RÉSUMÉ. Les auteurs ont étudié la diffusion d'un mélange de sels de chrome et de lubrifiant dans la structure de la peau de mouton par la microscopie électronique à balayage. Les résultats ont confirmé la répartition homogène des composés de tannage au chrome dans la structure de la peau de mouton au cours du repos pendant 2 heures. Le produit fini réalisé selon une technologie innovante combinée de tannage et graissage au traitement mécanique intégré répond aux exigences réglementaires de TRCU 017/2011, «La sécurité des produits de l'industrie légère». La méthode innovante proposée, le tannage et le graissage par la diffusion du fluide de lubrification dans la structure de la peau de mouton, peut réduire considérablement le temps de traitement des peaux de mouton de 4 heures à 4,5 minutes, le temps de repos de 4 à 2 heures et peut réduire considérablement la consommation d'eau, réduisant ainsi l'émission d'effluents toxiques au chrome trivalent.

MOTS-CLÉS: tannage et graissage, émulsion de graissage au chrome, cuir, diffusion, microscopie électronique à balayage

\footnotetext{
* Correspondence to: Dmitry SHALBUEV, East Siberia State University of Technology and Management, 40 V Kluchevskaya St., Ulan-Ude, 670013, shalbuevd@mail.ru
} 


\section{INTRODUCTION}

The basis of the leather and fur production technology is skin processing in aqueous solutions of chemicals, interchanging with throughfeed and close-end machine working of semi-finished leather. Skins processing in an aqueous medium is relatively simple and inexpensive, but has some serious disadvantages: long permeation of aqueous colloidal solutions into the dermis structure, followed by fibers agglutination at dehydration forms a large amount of waste water requiring special treatment.

A major leather and fur production process is tanning, i.e. treating skins and furs to produce leather, which is suitable for footwear, clothing, fancy and other goods production. Interreactions of tanning substances with protein functional groups and cross bonding of protein polypeptide chains, leading to irreversible changes in their properties, occur during tanning process. Properties of both dermis and hair of leather and fur change under the influence of tanning agents of different chemical nature [1].

Mineral (chrome, aluminum), aldehyde, oil, vegetable tannage and combined types of tanning are currently used in leather and fur processing. A most common mixture for leather and fur tanning consists of chromium compounds (III), which were first used in the second half of the XIX century. Chromium compounds interreact with collagen carboxyl groups succeeded by formation of stable pentacycles. This does not prevent interaction of chromium compounds with other collagen functional groups, in particular with amino, hydroxyl or peptide groups. Skin should be loosened and have an acidic $\mathrm{pH}$, which is achieved after drenching and pickling to facilitate diffusion of tanning compounds into the dermis depth and penetration of collagen active groups into it.

Chromium tanning provides a good quality skin for long-term storage. For more than a hundred years chromium compounds have been used in tanning industry, but no appropriate substitution for chrome tanning has been found yet. Many researchers modified chrome tanning to reduce chromium (III) consumption, thus reducing its losses during leather manufacture. Nevertheless, until now from 25 to $40 \%$ of

\section{INTRODUCERE}

Baza tehnologiei de fabricare a pieilor și blănurilor o reprezintă prelucrarea pielii în soluții chimice apoase, transformându-se în piele semi-finită prin tratare utilizând utilaje specifice. Prelucrarea pieilor într-un mediu apos este relativ simplă și ieftină, dar are câteva dezavantaje serioase: pătrunderea îndelungată a soluțiilor coloidale apoase în structura dermei, urmată de lipirea fibrelor la deshidratare, are ca rezultat o mare cantitate de apă reziduală care necesită un tratament special.

Un proces major în cadrul fabricării pieilor și blănurilor este tăbăcirea, adică tratarea pieilor și blănurilor pentru a obține pielea finită, care este destinată fabricării de încălțăminte, îmbrăcăminte, produse de lux și alte bunuri. În timpul procesului de tăbăcire au loc reacțiile substanțelor tanante cu grupele funcționale ale proteinelor și reticularea lanțurilor polipeptidice ale proteinelor, care duc la schimbări ireversibile ale proprietăților acestora. Atât proprietățile dermei, cât și ale părului se modifică sub influența agenților tananți de natură chimică diferită [1].

În prezent, în procesul de prelucrare a pieilor și blănurilor se utilizează agenți tananți minerali (pe bază de crom, aluminiu), aldehide, ulei, agenți de tăbăcire vegetali și combinații ale diferitelor tipuri de agenți de tăbăcire. Un amestec uzual pentru tăbăcirea pieilor și blănurilor constă din compuși de crom (III), care au fost folosiți pentru prima dată în a doua jumătate a secolului al XIX-lea. Compușii de crom reacționează cu grupările carboxil ale colagenului formând pentacicluri stabile. Acest lucru nu împiedică interacțiunea compușilor de crom cu alte grupe funcționale ale colagenului, în special cu grupări amino, hidroxil sau peptide. Structura pielii trebuie să fie relaxată și să aibă un pH acid, obținut după înmuiere și piclare, pentru a facilita difuzia compușilor tananți în profunzimea dermei și pătrunderea în grupările active ale colagenului.

Prin tăbăcirea în crom se obține o piele de bună calitate care poate fi depozitată pe termen lung. Timp de mai bine de o sută de ani, în industria de pielărie s-au utilizat compușii de crom, însă nu s-a găsit încă un substitut corespunzător pentru tăbăcirea în crom. Mulți cercetători au modificat procesul de tăbăcire în crom pentru a reduce consumul de crom (III), reducând, prin urmare, 
chrome tanning agent gets into the effluents [2]. In fact, the overall chromium waste is yet more, taking into account all the chromium-containing waste:

- leather cuttings left after shaving of tanned skins;

- leather trimmings left after skins outlining or after mechanical operation of breaks and cutting for footwear components;

- leather scraps up to $7 \mathrm{dm}^{2}$ as a result of mechanical operations of tears or breaks, as well as waste from cutting skins for parts of footwear, saddlery and clothing goods;

- leather splits from 4 to $7 \mathrm{dm}^{2}$ left after chrome tanning, which are subdivided into footwear, haberdashery and underlayment.

World leather industry annually consumes about 65 thousand tons of chromium. 45 thousand tons of chromium is left in leather goods, the rest goes into solid and liquid waste, which can lead to general toxic, allergenic, carcinogenic and mutagenic effects on living organisms.

A comprehensive solution to environmental problems is possible only by developing innovative methods of chemicals penetration into the leather structure. An advanced method elaborated by the authors of the article is a technological process of sheepskin leather processing at a tanning and greasing stage. Greasing, as well as tanning, is an important process of leather and fur production. It is a process of coating leather fabrics by oil. Oil is absorbed on the surface and penetrates between structural elements of leather splitting them to plasticize, soften, attain higher tenacity and improve water resistance property. This innovative method of emulsion introduction into the structure, developed by the authors, enables not only the combination of tanning and greasing processes but also intensifies them by integrated mechanical effect on leather and tanning and greasing emulsion. All this will greatly reduce trivalent chromium and greasing substances flow into drainage, while maintaining high quality of the finished product [3].

Working mixture penetration into semifinished leather is due to diffusion during nonmoving and slow-moving processes. The și pierderile în timpul fabricării pielii. $\mathrm{Cu}$ toate acestea, în prezent, în efluenți ajunge o cantitate de agent de tăbăcire cu crom de la 25 până la $40 \%$ [2]. De fapt, cantitatea generală de deșeuri de crom este și mai mare, luând în considerare toate deșeurile cu conținut de crom:

- resturi de piele rămase după fălțuirea pieilor tăbăcite;

- ștuțuitură rămasă după operația mecanică de ștuțuire sau după croirea componentelor pentru încălțăminte;

- resturi de piele de până la $7 \mathrm{dm}^{2}$, rupte în urma unor operații mecanice, precum și deșeuri de la tăierea pieilor pentru componente de încălțăminte, harnașamente și articole de îmbrăcăminte;

- șpalturi de piele de la 4 la 7 dm² $^{2}$ rămase după tăbăcirea în crom, care sunt subdivizate în articole de încălțăminte, galanterie și căptușeli.

Industria de pielărie mondială consumă anual circa 65 mii de tone de crom. În produsele de piele rămân 45 de mii de tone de crom, iar restul reprezintă deșeuri solide și lichide, care pot duce la efecte toxice, alergene, cancerigene și mutagene generale asupra organismelor vii.

O soluție completă la problemele de mediu este posibilă numai prin dezvoltarea unor metode inovatoare de introducere a produselor chimice în structura pielii. O metodă avansată elaborată de autorii acestui articol este un proces tehnologic de prelucrare a pieilor de oaie, în etapa de tăbăcire și de ungere. Ungerea, ca și tăbăcirea, este un proces important în cadrul fabricării pieilor și blănurilor. Aceasta presupune acoperirea suprafeței pielii cu un strat de ulei. Uleiul este absorbit pe suprafață și pătrunde între elementele structurale ale pielii, separându-le pentru a obține un efect de plastifiere, moliciune, pentru a obține o durabilitate mai mare și pentru a îmbunătăți proprietatea de rezistență la apă. Această metodă inovatoare de introducere a emulsiei în structură, dezvoltată de autori, nu permite doar combinarea proceselor de tăbăcire și de ungere, ci și intensificarea acestora printr-un efect mecanic integrat asupra pielii și al emulsiei de tăbăcire și ungere. Toate acestea vor reduce foarte mult cantitatea de crom trivalent și de substanțe de ungere din efluent, păstrând în același timp calitatea înaltă a produsului finit [3].

Pătrunderea amestecului în pielea semifinită se datorează difuziei în timpul proceselor 
diffusion time is influenced by temperature, concentration and viscosity of the working solution, the float ratio (FL), structure condition before soaking, mechanical, physical and other effects on semi-finished leather and working solution. A significant strength increase, viscosity reduction of the working solutions and mechanical treatment intensify chemical interaction between the agent and leather, accelerating liquid operation. Increasing mechanical impact and its certain change can bring to minor diffusion, but working substances penetration into semi-finished product will be due to injection into the capillary and microcapillary tubes of the sheepskin. Mechanical effect in this case can be carried out by stretchingcompression and bending deformation of semifinished leather. Compressional deformation leads to a "sponge" effect, i.e. leather disposes solution with a lowered concentration of the treatment substances at compression, and when the load is removed it adsorbs the solution with increased concentration. Bending deformation result in repositioning of capillaries in the skin, which are periodically opened and closed, sponging up the working solution (Figure 1). fără mișcare și cu mișcare lentă. Timpul de difuzie este influențat de temperatură, concentrația și vâscozitatea soluției de lucru, raportul de flotă $(\mathrm{FL})$, condiția structurii înainte de înmuiere, efectele mecanice, fizice și de altă natură asupra pielii semi-finite și soluția de lucru. O creștere semnificativă a rezistenței, reducerea vâscozității soluțiilor de lucru și tratarea mecanică intensifică interacțiunea chimică dintre agent și piele, accelerând acțiunea lichidului. Creșterea impactului mecanic și modificarea acestuia poate duce la o difuzie minoră, dar pătrunderea substanțelor în produsul semi-finit va avea loc datorită injectării acestora în tuburile capilare și microcapilare ale pielii de oaie. Efectul mecanic, în acest caz, poate fi determinat prin solicitări la întindere-compresiune și deformare la îndoire ale pielii semi-finite. Deformarea prin compresiune conduce la un efect de "burete", adică la compresiune pielea cedează soluție cu o concentrație scăzută de substanțe de tratare, iar atunci când sarcina este îndepărtată, aceasta adsoarbe soluția cu concentrație crescută. Deformarea la îndoire are ca rezultat repoziționarea capilarelor din piele, care sunt deschise și închise în mod periodic, absorbind soluția de lucru (Figura 1).

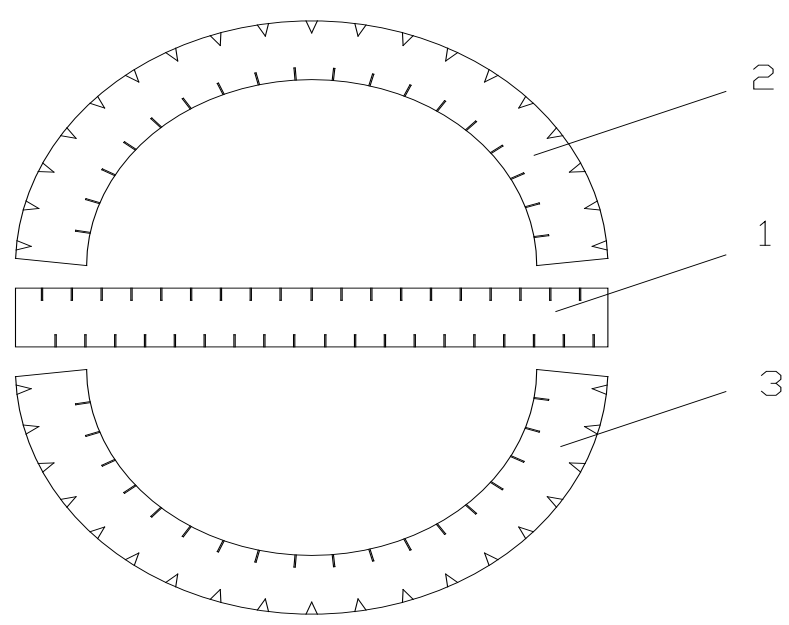

Figure 1. Position changing of the sheepskin capillaries:

1 - sheepskin, 2, 3 - sheepskin, subjected to bending deformation, stretching-compression

Figura 1. Modificarea poziţiei capilarelor din pielea de oaie:

1 - piele de oaie, 2, 3 - piele de oaie supusă deformării prin îndoire, întindere-comprimare

The purpose of the work was to study chrome-greasing fluid diffusion into the sheepskin structure during combined brushing method of tanning and greasing.
Obiectivul acestei lucrări a fost de a studia difuzia agenților de ungere și de cromare în structura pielii de oaie la aplicarea metodei de tăbăcire și ungere prin periere. 


\section{MATERIALS AND METHODS}

The object of the study was flint-dried sheepskin, preliminary exposed to soaking, degreasing, fleshing and pickling. The process of combined brushing method of tanning and greasing was performed on symmetrical sheepskin halves according to two ways (Table 1 ).

\section{MATERIALE ȘI METODE}

Studiul a fost efectuat utilizând piele de oaie cu blană uscată pe piatră, în prealabil înmuiată, degresată, șeruită și piclată. Metoda combinată de tăbăcire și ungere prin periere s-a aplicat pe piei de oaie cu blană tăiate în jumătăți simetrice în două moduri (Tabelul 1).

Table 1: Parameters of combined brushing method of woolskin tanning and greasing

Tabelul 1: Parametrii metodei combinate de tăbăcire şi ungere prin periere a pielii de oaie

\begin{tabular}{|c|c|c|c|c|c|c|}
\hline $\begin{array}{c}\text { Tanning } \\
\text { and greasing } \\
\text { method } \\
\text { Metoda } \\
\text { de tăbăcire şi } \\
\text { ungere }\end{array}$ & $\begin{array}{l}\text { Chemical name } \\
\text { and } \\
\text { consumption } \\
\text { Denumirea } \\
\text { şi consumul } \\
\text { substanţelor } \\
\text { chimice }\end{array}$ & $\begin{array}{c}\text { Temperature } \\
\text { of the process, }{ }^{\circ} \mathrm{C} \\
\text { Temperatura } \\
\text { procesului, }{ }^{\circ} \mathrm{C}\end{array}$ & $\begin{array}{l}\text { Time, min. } \\
\text { Timp, min. }\end{array}$ & $\begin{array}{c}\text { Duration of } \\
\text { the process, } \mathrm{h} \text {. } \\
\text { Durata } \\
\text { procesului, } h\end{array}$ & $\begin{array}{c}\text { Water } \\
\text { consumption, } \\
\mathrm{sm}^{3} / \mathrm{dm}^{2} \\
\text { Consumul } \\
\text { de apă, } \\
\mathrm{sm}^{3} / \mathrm{dm}^{2}\end{array}$ & $\begin{array}{l}\text { Waste } \\
\text { water } \\
\text { volume, } \\
\mathrm{sm}^{3} / \mathrm{dm}^{2} \\
\text { Volum } \\
\text { apă uzată, } \\
\mathrm{sm}^{3} / \mathrm{dm}^{2}\end{array}$ \\
\hline $\begin{array}{l}\text { Brushing with } \\
\text { mechanical } \\
\text { treatment }\end{array}$ & $\begin{array}{c}\text { Tanning and } \\
\text { greasing } \\
\text { emulsion }-3 \mathrm{sm}^{3} /\end{array}$ & & & & & \\
\hline $\begin{array}{c}\text { Aplicare prin } \\
\text { periere cu } \\
\text { prelucrare } \\
\text { mecanică }\end{array}$ & $\begin{array}{c}\mathrm{dm}^{2} \\
\text { Emulsie de } \\
\text { tăbăcire şi ungere } \\
-3 \mathrm{sm}^{3} / \mathrm{dm}^{2}\end{array}$ & $24 \pm 2$ & 4.5 & 2 & 0.67 & 0.0 \\
\hline $\begin{array}{c}\text { Brushing without } \\
\text { mechanical } \\
\text { treatment }\end{array}$ & $\begin{array}{l}\text { Tanning and } \\
\text { greasing } \\
\text { emulsion }-3 \mathrm{sm}^{3} /\end{array}$ & & & & & \\
\hline $\begin{array}{c}\text { Aplicare prin } \\
\text { periere fără } \\
\text { prelucrare } \\
\text { mecanică }\end{array}$ & $\begin{array}{c}\mathrm{dm}^{2} \\
\text { Emulsie de } \\
\text { tăbăcire şi ungere } \\
-3 \mathrm{sm}^{3} / \mathrm{dm}^{2}\end{array}$ & $24 \pm 2$ & 4.0 & 24 & 0.67 & 0.0 \\
\hline $\begin{array}{l}\text { Dipping } \\
\text { Imersiune }\end{array}$ & 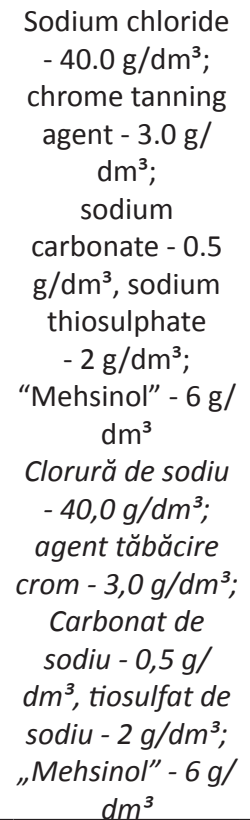 & $38 \pm 2$ & 240.0 & 4 & 386.2 & 347.6 \\
\hline
\end{tabular}


As reflected by the data in Table 1, experimental samples were tanned and greased by brushing method with and without mechanical treatment. Dipping method of tanning and greasing according to the standard technology of woolskin curing was a control sample.

The first method (mode 1), proposed by the authors, involves applying emulsion to the woolskin leather surface, which contains chromium compounds (hydrophilic phase), a mixture of greasing substances (hydrophobic phase) and surfactants (a stabilizer) with integrated mechanical action of tanning and greasing machine (Figure 2), taking into account selected processing modes at the preliminary stage [4]: relative deformation of semi-finished leather $\varepsilon=10 \%$; action frequency on semi-finished leather $v=0.04 \mathrm{~Hz}$; the number of cycles $n=9$.

Tanning and greasing emulsion was applied to woolskin leather surface by irrigation method at a rate of $3 \mathrm{sm}^{3} / \mathrm{dm}^{2}$, then woolskins were subjected to cyclic stretching-compression on a tanning and greasing machine for $4.5 \mathrm{~min}$., afterwards they were folded flesh sides together and left for ageing for 2 hours [5].

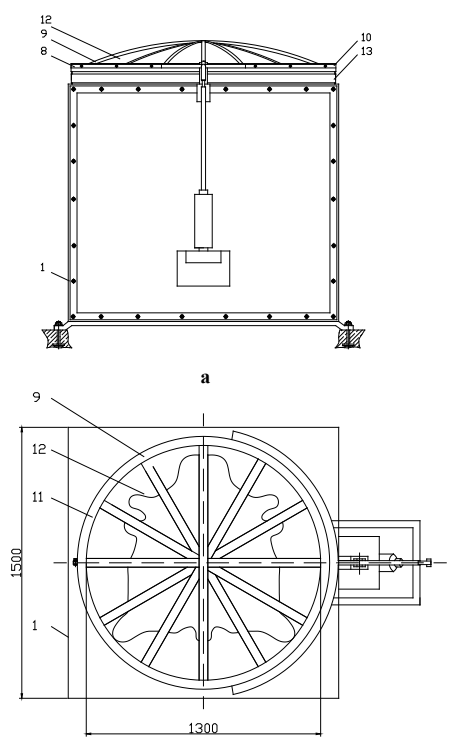

Așa cum reflectă datele din Tabelul 1, probele experimentale au fost tăbăcite și unse prin periere, cu și fără prelucrare mecanică. Proba martor a fost prelucrată prin metoda de tăbăcire și ungere prin imersiune conform tehnologiei standard de prelucrare a blănurilor.

Prima metodă (metoda 1), propusă de autori, presupune aplicarea emulsiei pe suprafața pielii cu blană, emulsie care conține compuși de crom (faza hidrofilă), un amestec de substanțe de ungere (faza hidrofobă) și agenți activi de suprafață (un stabilizator) cu acțiunea mecanică integrată de tăbăcire și ungere a unui utilaj (Figura 2), luând în considerare metodele de prelucrare selectate în etapa preliminară [4]: deformarea relativă a semi-fabricatelor de piele $\varepsilon=10 \%$; frecvența de acțiune asupra semi-fabricatelor de piele $v=0,04 \mathrm{~Hz}$; numărul de cicluri $n=9$.

Emulsia de tăbăcire și ungere a fost aplicată pe suprafața pielii cu blană prin metoda de irigare cu un debit de $3 \mathrm{sm}^{3} / \mathrm{dm}^{2}$, apoi pieile au fost supuse solicitărilor de întindere-compresiune ciclice folosind un utilaj de tăbăcire și ungere timp de 4,5 min., după care au fost împăturite pe partea cu carne și lăsate la odihnă timp de 2 ore [5].

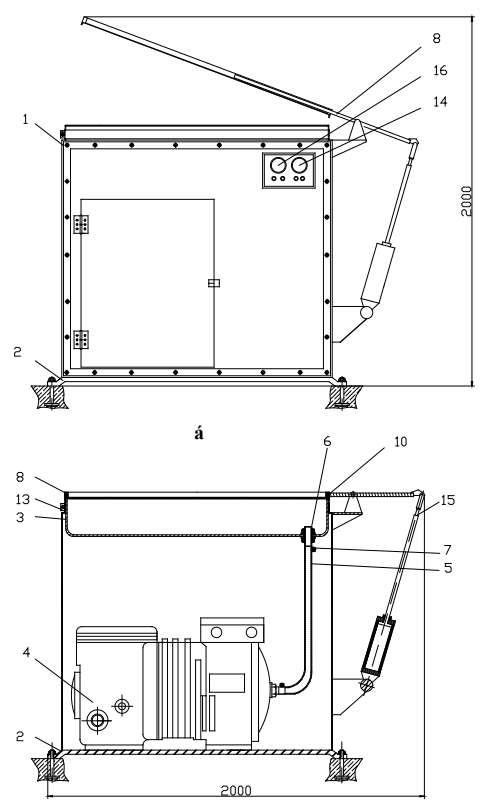

Figure 2. Tanning and greasing machine for semi-finished sheepskin: 1 - body, 2 - base, 3 - cylindrical tank, 4 - compressor, 5 - flexible hose, 6 - tube, 7 - collar, 8 - cover, 9 - rubber belt, 10 - collar, 11 - rubber membrane, 12 - sheepskin, 13 - mounting, 14 - control valve, 15 - pneumatic drive, 16 - control console ( $\mathrm{a}$ - front view, b - view with the raised cover, c - top view, $d$ - cross sectional view)

Figura 2. Utilaj de tăbăcire şi ungere pentru pieile de oaie semi-finite: 1 - carcasă, 2 - bază, 3 - rezervor cilindric, 4 - compresor, 5 - furtun flexibil, 6 - tub, 7 - manşon, 8 - capac, 9 - bandă cauciuc, 10 - manşon, 11 - membrană cauciuc, 12 - piele de oaie, 13 - cadru, 14 - supapă control, 15 - acţionare pneumatică, 16 - panou control ( $a$ - vedere faţă, $b$ - vedere cu capacul ridicat, c - vedere de sus, $d$ - vedere în secţiune) 
The second method of tanning and greasing (mode 2) was performed without mechanical action, according to the woolskins processing technology practiced in ECOM "Small innovative company" LLC (Ulan-Ude, Russia). Tanning and greasing emulsion was applied to woolskin leather surface by irrigation method at a rate of $3 \mathrm{sm}^{3} / \mathrm{dm}^{2}$, evenly distributing it over the entire surface. The treatment duration was 5-10 minutes. After emulsion applying sheepskins were folded flesh sides together and left for ageing for 24 hours.

The third method of tanning and greasing (mode 3 ) was performed by dipping according to the woolskins processing technology practiced in ECOM "Small innovative company" LLC (Ulan-Ude, Russia). Sheepskin samples were dipped into the working solution containing chromium tanning agent and sodium chloride at a temperature of $38 \pm 2^{\circ} \mathrm{C}$ for 4 hours after pickling process. Tannin basicity was $38 \%$. After tanning and greasing processes sheepskins were folded flesh sides together and left for ageing for 4 hours.

As reflected by the data in Table 1, application of tanning and greasing by brushing method with mechanical action (mode 1 ) reduces water consumption by $99.83 \%$ (from $386.2 \mathrm{sm}^{3}$ / $\mathrm{dm}^{2}$ to $0,67 \mathrm{sm}^{3} / \mathrm{dm}^{2}$ ), and reduces duration of tanning and greasing process from 4 hours to 4.5 minutes and ageing from 24 to 2 hours.

Tanning and greasing emulsion, estimated by the following parameters: dynamic viscosity, aggregative and sorption stability, was used for experimental samples.

Aggregative stability was measured in a measuring cylinder at a temperature of $40 \pm 2^{\circ} \mathrm{C}$ for the time period during which the emulsion completely separates into layers.

Five drops of tanning and greasing emulsion were applied to pickled pelts to determine sorption stability and the time for emulsion splitting (during which chromium drops appeared on the pelt surface) was figured out.

Rheotest was used to find out dynamic viscosity by means of cone-plate measuring device, able to work large shear stresses. To do so, $0.144 \mathrm{~g}$ of emulsion was applied to the surface of the measuring plate. The plate was
Cea de a doua metodă de tăbăcire și ungere (metoda 2) s-a realizat fără acțiune mecanică, conform tehnologiei de prelucrare a pieilor cu blană practicate în companiile inovatoare mici (Ulan-Ude, Rusia). Emulsia de tăbăcire și ungere a fost aplicată pe suprafața pieilor prin metoda de irigare cu un debit de 3 $\mathrm{sm}^{3} / \mathrm{dm}^{2}$, distribuindu-se uniform pe întreaga suprafață. Durata tratamentului a fost de 5-10 minute. După aplicarea emulsiei, pieile de oaie au fost împăturite pe partea cu carne și lăsate la odihnă timp de 24 de ore.

A treia metodă de tăbăcire și ungere (metoda 3) s-a realizat prin imersiune în conformitate cu tehnologia de prelucrare a pieilor practicată în companiile inovatoare mici (Ulan-Ude, Rusia). Probele de piele de oaie s-au imersat în soluția de lucru ce conține agent tanant pe bază de crom și clorură de sodiu la o temperatură de $38 \pm 2^{\circ} \mathrm{C}$ timp de 4 ore după procesul de piclare. Bazicitatea soluției tanante a fost de $38 \%$. După procesele de tăbăcire și gresare, pieile au fost împăturite pe partea cu carne și lăsate la odihnă timp de 4 ore.

După cum arată datele din Tabelul 1, aplicarea emulsiei de tăbăcire și ungere prin periere cu acțiune mecanică (metoda 1 ) reduce consumul de apă cu $99,83 \%$ (de la $386,2 \mathrm{sm}^{3} / \mathrm{dm}^{2}$ la $0,67 \mathrm{sm}^{3} / \mathrm{dm}^{2}$ ) și reduce durata procesului de tăbăcire și de ungere de la 4 ore la 4,5 minute și timpul de odihnă de la 24 de ore la 2 ore.

Emulsia de tăbăcire și ungere, evaluată în funcție de următorii parametri: vâscozitate dinamică, stabilitate la agregare și stabilitatea sorbției, a fost utilizată pentru probele experimentale.

Stabilitatea la agregare a fost măsurată într-un cilindru gradat, la o temperatură de $40 \pm 2^{\circ} \mathrm{C}$, în perioada de timp în care emulsia se separă complet în straturi.

Cinci picături din emulsia de tăbăcire și ungere au fost aplicate pe piei piclate pentru a determina stabilitatea absorbției și timpul de descompunere al emulsiei (s-a înregistrat timpul în care picăturile de crom au apărut pe suprafața pielii gelatină).

S-a determinat vâscozitatea dinamică cu dispozitivul de măsurare Rheotest cu placă con, capabil să lucreze la tensiuni mari de forfecare. Pentru aceasta s-au aplicat 0,144 g 
inserted into the guideway, tensioning lever was pressed, plate's position was set to the approach value of 6.49, while the test material was evenly distributed over the V-shaped surface. An indicating instrument measured the data to calculate $\alpha$ angle and frequencies.

The results are given in Table 2 . de emulsie pe suprafața plăcii de măsurare. Placa a fost introdusă în calea de ghidaj, levierul de tensionare a fost apăsat, poziția plăcii a fost stabilită la valoarea de 6,49, iar materialul de testat a fost distribuit uniform pe suprafața în formă de $\mathrm{V}$. Unghiul $\alpha$ și frecvențele au fost calculate utilizând un instrument de măsurare a datelor.

Rezultatele sunt prezentate în Tabelul 2.

Table 2: Tanning and greasing emulsion properties

Tabelul 2: Proprietăţile emulsiei de tăbăcire şi ungere

\begin{tabular}{|c|c|c|}
\hline $\begin{array}{c}\text { № } \\
\text { Nr. crt. }\end{array}$ & $\begin{array}{l}\text { Indicator } \\
\text { Indicator }\end{array}$ & $\begin{array}{l}\text { Indicator value } \\
\text { Valoare indicator }\end{array}$ \\
\hline 1 & $\begin{array}{l}\text { Aggregative stability, min. } \\
\text { Stabilitate la agregare, min. }\end{array}$ & $2889^{\prime}$ \\
\hline 2 & $\begin{array}{l}\text { Sorption stability, min. } \\
\text { Stabilitatea sorbţiei, min. }\end{array}$ & $>60^{\prime}$ \\
\hline 3 & $\begin{array}{l}\text { Dynamic viscosity, mPas } \times s \\
\text { Viscozitatea dinamică, mPas } \times s\end{array}$ & $276.84 \pm 21.11$ \\
\hline
\end{tabular}

Analyzing the data in Table 2 it can be noted that the emulsion is characterized by relatively high aggregative stability, low sorption stability and dynamic viscosity. Thus, the emulsion can be recommended as the main working solution for tanning and greasing by brushing method.

Conventional and modern research methods were used to determine the diffusion rate of chromium compounds into the leather structure and their interaction with the protein functional groups.

The diffusion process of chromium compounds into the sheepskin depth was estimated on the cure temperature change. For this purpose, the test sheepskins were dehaired and their thickness was measured according to the State Standard 32078-2013 "Cured fur skins and sheepskins. A method for determining cure temperature". If leather thickness was less than $0.5 \mathrm{~mm}$, the sample's width should be $5 \mathrm{~mm}$. If the thickness was $0.5 \mathrm{~mm}$ and more, the width should be $3 \mathrm{~mm}$. Two punctures were made on the midline at a distance of $3 \mathrm{~mm}$ from the samples' edges to fix the samples on device hooks. They were fixed on nonmoving and moving hooks and dipped into a glass of distilled water. The cure temperature (in Celsius degrees)
Analizând datele din Tabelul 2, se poate observa că emulsia se caracterizează printr-o stabilitate la agregare relativ ridicată, stabilitatea sorbției și vâscozitatea dinamică scăzute. Astfel, emulsia poate fi recomandat ca soluție principală de lucru pentru tăbăcire și ungere prin periere.

$\mathrm{S}$-au utilizat metode de cercetare convenționale și moderne pentru a determina rata de difuzie a compușilor de crom în structura pielii și interacțiunea acestora cu grupările funcționale ale proteinelor.

Procesul de difuzie a compușilor de crom în structura pielii de oaie a fost evaluat în funcție de modificarea temperaturii de prelucrare. În acest scop, s-a îndepărtat părul de pe probele de piele de oaie de testat, iar grosimea acestora a fost măsurată în conformitate cu standardul național 32078-2013, „Piei cu blană și piei de oaie prelucrate. Metodă de determinare a temperaturii de prelucrare". Dacă grosimea pielii a fost mai mică de $0,5 \mathrm{~mm}$, lățimea probei trebuie să fie de $5 \mathrm{~mm}$. Dacă grosimea a fost de minim 0,5 $\mathrm{mm}$, lățimea trebuie să fie de $3 \mathrm{~mm}$. S-au făcut două găuri pe linia mediană, la o distanță de 3 $\mathrm{mm}$ de la marginile probelor pentru prinderea probelor de cârligele dispozitivului. Acestea au fost prinse de cârlige fixe și mobile și imersate 
was determined at the time when the sample started to shrink and the arrow of a traversing pulley drifted from zero position.

Investigation of the leather structure was carried out by the scanning electron microscope 'JSM-6510LV JEOL' with 'INCA Energy 350' microanalysis system (UK, 2008) at ESSUTM "Progress" common use center (Ulan-Ude, Russia). The sheepskin sample preparation, preliminary tanned, degreased and subjected to finishing operations, was carried out by dehydration.

The method of scanning electron microscopy (SEM) is sensing the sample's surface by electron probe. The summary of the test method is that the sample's surface is irradiated with a finely focused electron beam (its diameter is up to $5 \div 10 \mu \mathrm{m}$ ), by so-called electron probe, the sources of information are reflected and secondary electrons. This method enables to study the leather fine structure by visual observation and photo magnification by 10 to 30,000 times or more, providing sufficiently high resolution. Built-in INCA Energy 350 X-ray analyzer performs elemental analysis at a point, over section and area mapping. Elemental composition of micro volumes is found out by excited characteristic X-radiation. Examination of the samples was carried out under low and high vacuum [6].

Basic instrumentation of standard test methods was used to determine sheepskin quality characteristics: the State Standard 938.1-67 "Leather. A test method for moisture content", Russian National Standard 530132008 "Fur skins and cured sheepskins. A test method for chromium oxide (III)", the State Standard 17631-72 "Fur skins and curried sheepskins. A test method for ash residue in leather", Russian National Standard 530182008 "Fur skins and cured sheepskins. A test method for mass fraction of unconnected greasy substances", Russian National Standard 530172008 "Fur skins and cured sheepskins. A test method for $\mathrm{pH}$ of aqueous extract", Russian National Standard 52957-2008 "Fur skins and cured sheepskins. Mechanical testing", the State Standard 938.24-72 "Leather. A test method for moisture-retaining power", the State Standard 938.21-71 "Leather. A test method for water penetration and water penetration capacity in într-un pahar cu apă distilată. Temperatura de prelucrare (în grade Celsius) a fost determinată în momentul în care proba a început să se micșoreze și săgeata unui scripete deplasabil s-a îndepărtat de poziția zero.

Structura pielii a fost investigată utilizând un microscop electronic cu baleiaj JSM-6510LV JEOL cu sistem de microanaliză INCA Energy 350 (Marea Britanie, 2008), la centrul ESSUTM „Progress” (Ulan-Ude, Rusia). Proba de piele de oaie în prealabil tăbăcită, degresată și supusă operațiunilor de finisare a fost pregătită prin deshidratare.

Analiza de microscopie electronică de baleiaj (SEM) presupune scanarea suprafeței probei utilizând o sondă electronică. Pe scurt, metoda de analiză presupune iradierea suprafeței probei cu un fascicul de electroni îngust (diametrul este de până la $5 \div 10 \mu \mathrm{m}$ ), prin intermediul unei așa-numite sonde electronice, și obținerea informațiilor prin reflectarea electronilor secundari. Această metodă permite studierea structurii fine a pielii prin observare vizuală și fotografie mărită de 10 până la 30.000 de ori sau mai mult, oferind o rezoluție suficient de mare. Analizorul cu raze $X$ încorporat INCA Energy 350 efectuează analiza elementală într-un punct, la cartografierea suprafeței și a secțiunii transversale. Compoziția elementală a volumelor micro este determinată prin excitarea radiațiilor $X$ caracteristice. Probele au fost examinate sub vid scăzut și ridicat [6].

S-au utilizat instrumentele de bază specifice metodelor de testare standard pentru a determina calitatea pielii de oaie: standardul de stat 938.1-67, „Piele. Metodă de încercare pentru conținutul de umiditate", standardul național rus 53013-2008, „Blănuri și piei de oaie prelucrate. Metodă de determinare a oxidului de crom (III)”, standardul de stat 17631-72, „Blănuri și piei de oaie prelucrate. Metodă de determinare a reziduurilor de cenușă din piele", standardul național rus 53018-2008, „Blănuri și piei de oaie prelucrate. Metodă de determinare a fracțiunii de masă a substanțelor grase nelegate", standardul național rus 53017-2008, „Blănuri și piei de oaie prelucrate. Metodă de determinare a $\mathrm{pH}$-ului extractului apos", standardul național rus 529572008, „Blănuri și piei de oaie prelucrate. Testare mecanică”, standardul de stat 938.24-72, „Piele. Metodă de determinare a capacității de reținere 
static conditions", Russian National Standard ISO 17229-2009 "Leather. A test method for vapor capacity".

Processing of experimental results was carried out by methods of mathematical statistics.

\section{RESULTS AND DISCUSSION}

The effectiveness of tanning and greasing by brushing method and therefore, the process of chromium compounds diffusion into the leather depth was evaluated by cure temperature change of leather in 0, 1, 2, 3, 4, 6, 8 and 24 hours ageing after tanning and greasing treatment (table 3 ). a umidității", standardul de stat 938.21-71, „Piele. Metodă de determinare a penetrării apei și a capacității de penetrare a apei în condiții statice", standardul național rus ISO 17229-2009, „Piele. Metodă de determinare a capacității vaporilor".

Rezultatele experimentale au fost prelucrate prin metode de statistică matematică.

\section{REZULTATE ȘI DISCUȚII}

Eficacitatea metodei de tăbăcire și ungere prin periere și, prin urmare, difuzia compușilor de crom în piele au fost evaluate prin modificarea temperaturii de contracție a pielii după $0,1,2,3$, 4, 6, 8 și 24 de ore după tratamentul de tăbăcire și ungere (Tabelul 3).

Table 3: Change in sheepskin cure temperature during ageing, depending on the processing mode

Tabelul 3: Modificarea temperaturii de contracţie a pielii de oaie în perioada de odihnă, în funcţie de metoda de prelucrare

\begin{tabular}{|c|c|c|c|c|c|c|c|c|}
\hline $\begin{array}{l}\text { Tanning and greasing mode } \\
\text { Metodă de tăbăcire şi ungere }\end{array}$ & 0 & $\begin{array}{c}1 \\
\text { Cure tem } \\
\text { Temperat }\end{array}$ & $\begin{array}{l}2 \\
\text { ture, oc } \\
\text { le contr }\end{array}$ & $\begin{array}{l}\text { Ageing } \\
\text { mp de } \\
3 \\
e,-C\end{array}$ & $\begin{array}{l}\mathrm{h} \\
n a ̆, h \\
4\end{array}$ & 6 & 8 & 24 \\
\hline $\begin{array}{l}\text { Brushing with mechanical } \\
\text { treatment } \\
\text { Aplicare prin periere cu prelucrare } \\
\text { mecanică }\end{array}$ & $48 \pm 2$ & 2 & $81 \pm 2$ & $81 \pm 2$ & $82 \pm 2$ & $82 \pm 2$ & $83 \pm 2$ & $84 \pm 2$ \\
\hline $\begin{array}{l}\text { Brushing without mechanical } \\
\text { treatment } \\
\text { Aplicare prin periere fără } \\
\text { prelucrare mecanică }\end{array}$ & $48 \pm 2$ & $62 \pm 2$ & $63 \pm 2$ & $63 \pm 2$ & $64 \pm 2$ & $65 \pm 2$ & $66 \pm 2$ & $74 \pm 2$ \\
\hline $\begin{array}{l}\text { Dipping } \\
\text { Imersiune }\end{array}$ & $48 \pm 2$ & $62 \pm 2$ & $66 \pm 2$ & $68 \pm 2$ & $70 \pm 2$ & $75 \pm 2$ & $78 \pm 2$ & $83 \pm 2$ \\
\hline
\end{tabular}

The results in Table 3 show a gradual increase in cure temperature of the sheepskin during 24 hours of ageing regardless of the tanning and greasing method. For modes 1 and 3 it is up to $83-84 \pm 2^{\circ} \mathrm{C}$, for mode 2 it is up to $74 \pm 2^{\circ} \mathrm{C}$. The intense cure temperature change of the sheepskin is related to the experimental sample with an integrated mechanical action. The cure temperature exceeds $80^{\circ} \mathrm{C}$ for two hours of ageing after brushing method of tanning and greasing with a mechanical action, whereas the cure temperature averages $65^{\circ} \mathrm{C}$ for the other treatment options during the given period of time.

The data obtained proves that combined brushing method of tanning and greasing with a complex mechanical action of the tanning and greasing machine (Figure 2) with regard
Rezultatele din Tabelul 3 arată o creștere treptată a temperaturii de contracție a pielii de oaie într-o perioadă de 24 de ore de odihnă, indiferent de metoda de tăbăcire și ungere folosită. În cazul metodelor 1 și 3, temperatura este de până la $83-84 \pm 2^{\circ} \mathrm{C}$, iar pentru metoda 2 , este de până la $74 \pm 2^{\circ} \mathrm{C}$. Modificarea temperaturii de contracție a pielii este valabilă pentru proba experimentală cu acțiune mecanică integrată. Temperatura de contracție depășește $80^{\circ} \mathrm{C}$, după două ore de odihnă în cazul aplicării metodei de tăbăcire și ungere prin periere cu prelucrare mecanică, în timp ce temperaturile medii de contracție de $65^{\circ} \mathrm{C}$ s-au obținut pentru celelalte tipuri de tratament în perioada de timp specificată.

Referitor la metodele de prelucrare alese în prealabil [4]: deformarea relativă a semifabricatelor de piele $\varepsilon=10 \%$, frecvența de 
to preliminary chosen processing modes [4]: relative deformation of semi-finished leather $\varepsilon=$ $10 \%$; action frequency on semi-finished leather $v$ $=0.04 \mathrm{~Hz}$; the number of cycles $\mathrm{n}=9$ significantly reduces the process time to $4.5 \mathrm{~m}$, as well as intensifies the diffusion process of chrome tanning compounds into the leather structure.

It should be noted that the rate and depth of the emulsion penetration depends upon the degree of a mechanical action, duration of impact of working parts on semi-finished sheepskin surface and emulsion consumption per unit area of the leather. This effect is achieved due to the forced injection of the emulsion into the dermis depth, compression, stretching, skin surface friction while processing on the machine. These processes lead to leather structure deformation and achieve more complete emulsion penetration into the thickness of semifinished leather. Under the influence of various effects (sponge, capillary soaking, peristaltic, hydrodynamic indentation) emulsion is quickly "sucked" into the leather structure.

Cross-section micrographs of the samples at different time intervals after tanning and greasing were taken by scanning electron microscopy to get information about semifinished leather structural change, diffusion process intensity of chromium oxide into the leather depth and its distribution over the dermis thickness. The intensity of characteristic $\mathrm{K}-\alpha$ chromium radiation was found out and the elemental composition by X-ray microanalysis was carried out.

Figure 3 is a sheepskin cross-section micrograph before tanning and greasing, and it shows measuring points. acțiune asupra semi-fabricatelor de piele $v=$ $0,04 \mathrm{~Hz}$, numărul de cicluri $n=9$, datele obținute demonstrează că metoda de tăbăcire și ungere prin periere combinată cu o acțiune mecanică complexă a utilajului de tăbăcire și ungere (Figura 2) reduce semnificativ timpul de prelucrare până la 4,5 min. și intensifică difuzia compușilor tananți de crom în structura pielii.

Trebuie remarcat faptul că viteza și profunzimea penetrării emulsiei depinde de gradul acțiunii mecanice, durata impactului instrumentelor de lucru asupra semifabricatelor de piele și consumul de emulsie pe unitatea de suprafață a pielii. Acest efect este obținut datorită injectării forțate a emulsiei în profunzimea dermei, compresiunii, întinderii și fricțiunii care au loc la suprafața pielii în timpul prelucrării folosind utilajul descris. Aceste procese conduc la deformarea structurii pielii și la obținerea unei penetrări complete a emulsiei în profunzimea semi-fabricatelor de piele. Sub influența diferitelor efecte (de absorbție, umplerea capilarelor, efect peristaltic, indentare hidrodinamică), emulsia este absorbită rapid în structura pielii.

Micrografiile probelor în secțiune transversală efectuate la diferite intervale de timp după tăbăcire și ungere au fost realizate prin microscopia electronică de baleiaj pentru a obține informații despre modificarea structurală a semi-fabricatelor de piele, intensitatea procesului de difuzie a oxidului de crom în profunzimea pielii și distribuția acestuia pe toată grosimea dermei. S-au determinat intensitatea radiației K- $\alpha$ caracteristice cromului și compoziția elementală prin microanaliză cu raze $X$.

Figura 3 prezintă micrografia pielii de oaie în secțiune transversală înainte de tăbăcire și ungere, indicând punctele de măsurare.

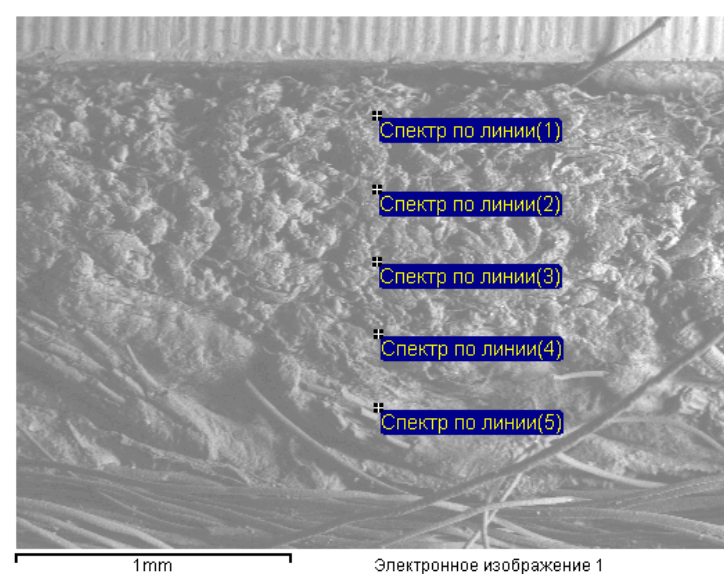

Figure 3. Measuring points on a sheepskin cross-section before tanning and greasing, $\times 50$

Figura 3. Puncte de măsurare pe seç̧iunea transversală a pielii de oaie înainte de tăbăcire şi ungere, $\times 50$ 
Table 4 presents the results of the elemental composition analysis of a sheepskin cross-section before tanning and greasing, obtained by X-ray microanalysis.
Tabelul 4 prezintă rezultatele analizei compoziției elementale a secțiunii transversale a pielii de oaie înainte de tăbăcire și ungere, obținute prin microanaliza cu raze $X$.

Table 4: Elemental composition analysis of a sheepskin cross-section before tanning and greasing $(w t \%), \times 50$

Tabelul 4: Analiza compoziţiei elementale a secţiunii transversale a pielii de oaie înainte de tăbăcire şi ungere $(w t \%), \times 50$

\begin{tabular}{|c|c|c|c|c|c|c|c|c|}
\hline $\begin{array}{l}\text { Spectrum } \\
\text { Spectru }\end{array}$ & C & 0 & $\mathrm{Na}$ & $\mathrm{Si}$ & $S$ & $\mathrm{Cl}$ & $\mathrm{Ca}$ & Total \\
\hline $\begin{array}{l}\text { Total spectrum } \\
\text { Spectru total }\end{array}$ & 47.77 & 36.18 & 7.49 & - & 4.98 & 3.05 & 0.54 & 100.00 \\
\hline $\begin{array}{l}\text { Line (1) spectrum } \\
\text { Spectru linia (1) }\end{array}$ & 41.41 & 34.53 & 12.95 & 0.36 & 7.73 & 2.78 & 0.25 & 100.00 \\
\hline $\begin{array}{l}\text { Line (2) spectrum } \\
\text { Spectru linia (2) }\end{array}$ & 48.87 & 31.56 & 6.79 & - & 6.82 & 5.57 & 0.39 & 100.00 \\
\hline $\begin{array}{l}\text { Line (3) spectrum } \\
\text { Spectru linia (3) }\end{array}$ & 58.56 & 28.40 & 5.83 & - & 3.68 & 3.36 & 0.17 & 100.00 \\
\hline $\begin{array}{l}\text { Line (4) spectrum } \\
\text { Spectru linia (4) }\end{array}$ & 36.29 & 41.17 & 13.44 & - & 6.78 & 1.82 & 0.50 & 100.00 \\
\hline $\begin{array}{l}\text { Line (5) spectrum } \\
\text { Spectru linia (5) }\end{array}$ & 58.86 & 34.24 & 2.54 & - & 2.45 & 1.91 & - & 100.00 \\
\hline Max. & 58.86 & 41.17 & 13.44 & 0.36 & 7.73 & 5.57 & 0.54 & \\
\hline Min. & 36.29 & 28.40 & 2.54 & 0.36 & 2.45 & 1.82 & 0.17 & \\
\hline
\end{tabular}

According to Figure 3 and Table 4, the sheepskin thickness was conventionally divided into five segments; each of them has been analyzed for elemental composition. A comparative study of the elemental composition in five points gave information on 7 elements: carbon (36-59\%), oxygen (28-41\%), sodium (2.5$13 \%)$, silicon, sulfur, chloride and calcium.

Figure 4 and Table 5 show the data obtained within 20 minutes after sheepskin tanning and greasing.

Analysis of the characteristic $\mathrm{K}-\alpha$ chromium radiation intensity, chromium ratio in the sheepskin cross sections (Figure 4, Table 5) show that within 20 minutes after tanning and greasing by brushing method with integrated mechanical processing, the diffusion of chromium tanning compounds into the leather structure is more intensive and equal to 0.42 $4.3 \%$ compared with the experimental samples without mechanical action (0.06-0.19\%) and control samples (0.01-0.69\%). Chrome tannin penetration into the leather structure with integrated mechanical action is more than $2 / 3$ of the semi-finished leather thickness. The diagram of chromium radiation intensity in cross sections of the control samples (tanning and greasing by brushing method without mechanical
Conform Figurii 3 și Tabelului 4, grosimea pielii de oaie a fost împărțită în mod convențional în cinci segmente; fiecare segment a fost analizat pentru a determina compoziția elementală. Un studiu comparativ al compoziției elementale în cinci puncte a oferit informații despre 7 elemente: carbon (36-59\%), oxigen (28-41\%), sodiu (2,5-13\%), siliciu, sulf, clorură și calciu.

Figura 4 și Tabelul 5 prezintă datele obținute la 20 de minute după tăbăcirea și ungerea pielii de oaie.

Analiza intensității radiației $\mathrm{K}-\alpha$ caracteristice cromului, conținutul de crom din secțiunile transversale ale pieilor de oaie (Figura 4, Tabelul 5) arată că, la 20 de minute după tăbăcire și ungere prin periere cu prelucrare mecanică integrată, difuzia compușilor tananți de crom în structura pielii este mai intensă și egală cu 0,42$4,3 \%$, comparativ cu probele experimentale fără prelucrare mecanică $(0,06-0,19 \%)$ și cu probele martor $(0,01-0,69 \%)$. Penetrarea cromului în structura pielii, cu acțiune mecanică integrată, reprezintă mai mult de $2 / 3$ din grosimea semifabricatului de piele. Diagrama intensității radiației cromului în secțiunea transversală a probelor martor (tăbăcire și ungere prin periere fără prelucrare mecanică, tăbăcire și ungere prin imersiune) prezintă o distribuție neuniformă a 

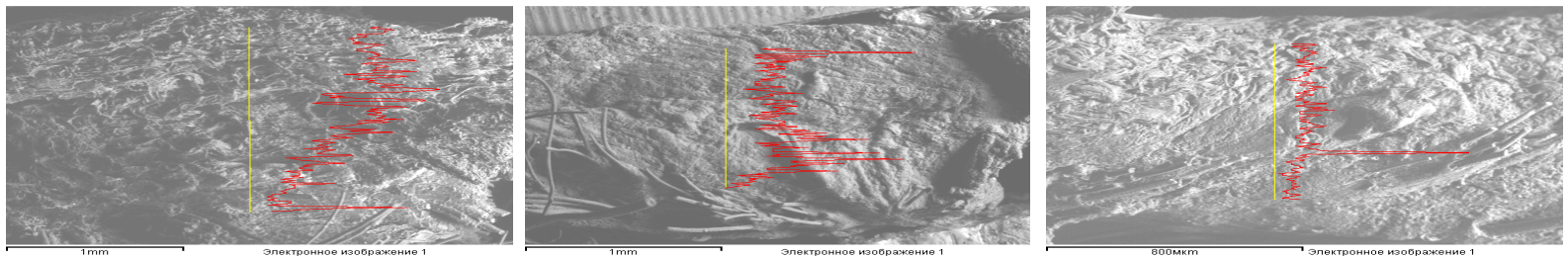

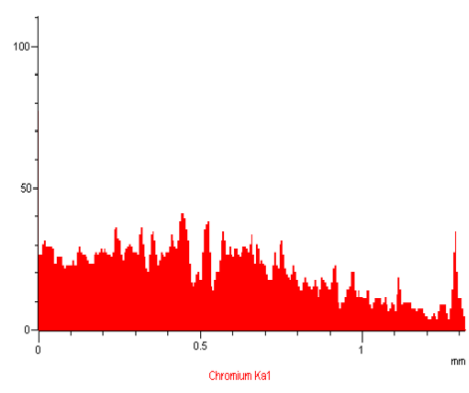

a

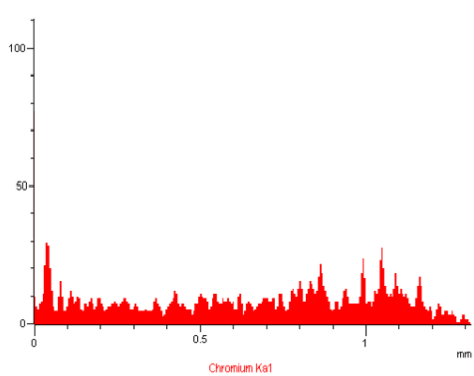

b

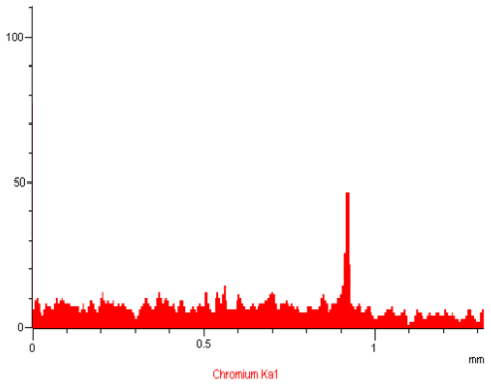

C

Figure 4. Diagram of the characteristic K- $\alpha$ chromium radiation intensity in the sheepskin crosssection in 20 minutes after treatment: a - Tanning and greasing by brushing method with mechanical action, $\mathrm{b}$ - Tanning and greasing by brushing method without mechanical action, $\mathrm{c}-$ tanning and greasing by dipping method; $\times 50$

Figura 4. Diagrama intensităţii radiaţiei K- $\alpha$ caracteristice cromului în secţiunea transversală a pielii de oaie după 20 de minute de tratament: a - tăbăcire şi ungere prin periere cu prelucrare mecanică, b - tăbăcire şi ungere prin periere fără prelucrare mecanică, $c$ - tăbăcire şi ungere prin imersiune; $\times 50$

Table 5: Chromium weight content in the sheepskin cross section in 20 minutes after treatment (wt\%) Tabelul 5: Conţinutul de crom din secţiunea transversală a pielii de oaie după 20 de minute de la tratament (wt\%)

\begin{tabular}{|c|c|c|c|}
\hline \multirow[b]{2}{*}{$\begin{array}{l}\text { Spectrum } \\
\text { Spectru }\end{array}$} & \multicolumn{3}{|c|}{$\begin{array}{c}\text { Chromium weight content, wt } \% \\
\text { Conţinut crom, calculat la greutate, wt\% }\end{array}$} \\
\hline & $\begin{array}{c}\text { Tanning and greasing by } \\
\text { brushing method with } \\
\text { mechanical treatment } \\
\text { Tăbăcire şi ungere prin } \\
\text { periere cu prelucrare } \\
\text { mecanică }\end{array}$ & $\begin{array}{l}\text { Tanning and greasing by } \\
\text { brushing method without } \\
\text { mechanical treatment } \\
\text { Tăbăcire şi ungere prin periere } \\
\text { fără prelucrare mecanică }\end{array}$ & $\begin{array}{l}\text { Tanning and greasing by } \\
\text { dipping method } \\
\text { Tăbăcire şi ungere prin } \\
\text { imersiune }\end{array}$ \\
\hline $\begin{array}{l}\text { Line (1) spectrum } \\
\text { Spectru linia (1) }\end{array}$ & 2.43 & 0.06 & - \\
\hline $\begin{array}{l}\text { Line (2) spectrum } \\
\text { Spectru linia (2) }\end{array}$ & 3.92 & 0.09 & 0.03 \\
\hline $\begin{array}{l}\text { Line (3) spectrum } \\
\text { Spectru linia (3) }\end{array}$ & 0.47 & 0.15 & 0.01 \\
\hline $\begin{array}{l}\text { Line (4) spectrum } \\
\text { Spectru linia (4) }\end{array}$ & 4.30 & 0.07 & 0.69 \\
\hline $\begin{array}{l}\text { Line (5) spectrum } \\
\text { Spectru linia (5) }\end{array}$ & 0.42 & 0.19 & - \\
\hline Max. & 4.30 & 0.19 & 0.69 \\
\hline Min. & 0.42 & 0.06 & 0.01 \\
\hline
\end{tabular}


processing, tanning and greasing by dipping method) shows uneven tannin distribution over the semi-finished leather thickness.

Figure 5 and Table 6 show the data obtained in 2 hours of soaking after tanning and greasing of sheepskin samples. taninului în grosimea semi-fabricatelor de piele.

Figura 5 și Tabelul 6 prezintă datele obținute la 2 ore de la înmuiere după tăbăcirea și ungerea probelor de piele.
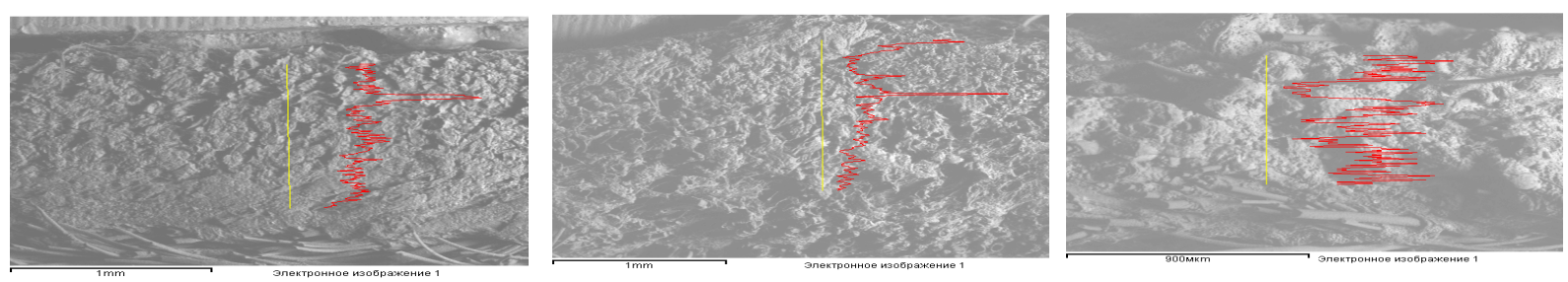

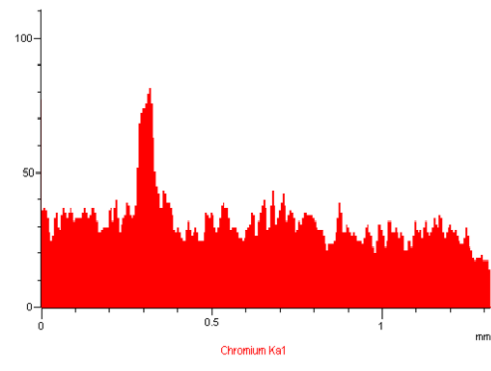

a

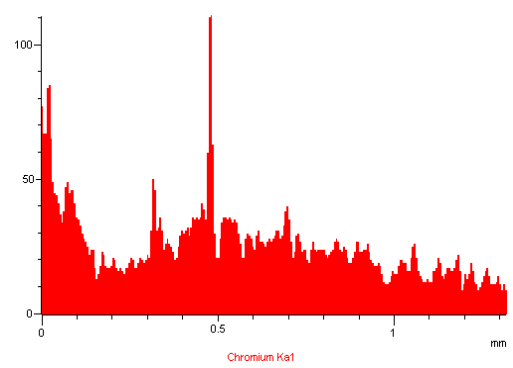

b

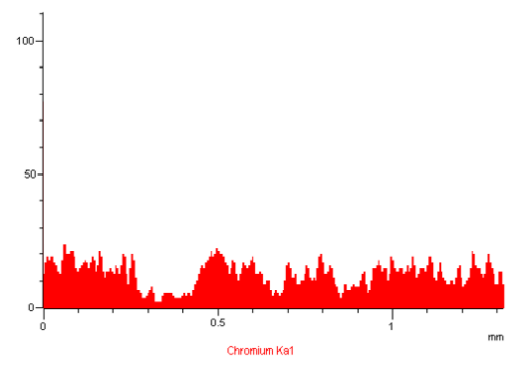

C

Figure 5 . Diagram of the characteristic K- $\alpha$ chromium radiation intensity in the sheepskin crosssection in 2 hours after the following treatments: a - Tanning and greasing by brushing method with mechanical treatment, $b-$ Tanning and greasing by brushing method without mechanical treatment, c - Tanning and greasing by dipping method; $\times 50$

Figura 5. Diagrama intensităţii radiaţiei K- $\alpha$ caracteristice cromului în secţiunea transversală a pielii de oaie după 2 ore de tratament: $a$ - tăbăcire şi ungere prin periere cu prelucrare mecanică, $b$ - tăbăcire şi ungere prin periere fără prelucrare mecanică, c - tăbăcire şi ungere prin imersiune; ×50

Table 6: Chromium weight content in the sheepskin cross section in 2 hours after treatment (wt\%) Tabelul 6: Conţinutul de crom din secţiunea transversală a pielii de oaie după 2 ore după tratament (wt\%)

\begin{tabular}{|c|c|c|c|}
\hline & & $\begin{array}{l}\text { Chromium weight content, wt } \% \\
\text { inut crom, calculat la greutate, wt\% }\end{array}$ & \\
\hline Spectrum & $\begin{array}{l}\text { Tanning and greasing by } \\
\text { brushing method with } \\
\text { mechanical treatment } \\
\text { Tăbăcire şi ungere prin periere } \\
\text { cu prelucrare mecanică }\end{array}$ & $\begin{array}{c}\text { Tanning and greasing by brushing } \\
\text { method without mechanical } \\
\text { treatment } \\
\text { Tăbăcire şi ungere prin periere } \\
\text { fără prelucrare mecanică }\end{array}$ & $\begin{array}{l}\text { Tanning and greasing by } \\
\text { dipping method } \\
\text { Tăbăcire şi ungere prin } \\
\text { imersiune }\end{array}$ \\
\hline $\begin{array}{l}\text { Line (1) spectrum } \\
\text { Spectru linia (1) }\end{array}$ & 4.53 & 1.95 & 0.01 \\
\hline $\begin{array}{l}\text { Line (2) spectrum } \\
\text { Spectru linia (2) }\end{array}$ & 16.23 & 6.63 & 0.08 \\
\hline $\begin{array}{l}\text { Line (3) spectrum } \\
\text { Spectru linia (3) }\end{array}$ & 4.56 & 2.82 & 1.01 \\
\hline
\end{tabular}


Line (4) spectrum

Spectru linia (4)

Line (5) spectrum

Spectru linia (5)

Max.

Min.
5.89

3.13

16.23

3.13
2.46

2.03

6.63

1.95
1.07

1.07

0.01
Tanner penetration is even practically all over the sheepskin thickness in 2 hours after tanning and greasing by brushing method with integrated mechanical treatment, while chromium weight content in the control samples shows uneven distribution of the tanner over the semi-finished leather thickness on the diagram of the characteristic $\mathrm{K}-\alpha$ chromium radiation intensity (Figure 4, Table 6).

Analysis of the data in Figures 4 and 5 , in Tables 5 and 6 is supported by the data in Table 3: when chromium ratio is $3 \div 5 \%$ cure temperature of the leather reaches the required $80^{\circ} \mathrm{C}$. Thus, the cure temperature of the leather correlates well with chromium oxide distribution in the investigated samples by $\mathrm{X}$-ray microanalysis.

Effectiveness of the combined sheepskin tanning and greasing with integrated mechanical treatment is proved by the research results. Semi-finished leather obtained by the proposed technology has high physical, mechanical and hygienic properties (Table 7).
Penetrarea tanantului este, practic, uniformă pe întreaga grosime a pielii la 2 ore după tăbăcire și ungere prin periere cu prelucrare mecanică integrată, în timp ce conținutul de crom calculat la greutatea pielii la probele martor arată distribuția inegală a tanantului pe grosimea semi-fabricatului de piele în diagrama intensității radiației $\mathrm{K}-\alpha$ caracteristice cromului (Figura 4, Tabelul 6).

Analiza datelor din Figurile 4 și 5 și Tabelele 5 și 6 este susținută de datele din Tabelul 3: atunci când procentul de crom este de $3 \div 5 \%$ față de greutatea pieilor piclate, temperatura de contracție a pielii ajunge la temperatura dorită, de $80^{\circ} \mathrm{C}$. Astfel, temperatura de contracție a pielii se corelează bine cu distribuția oxidului de crom în probele investigate prin microanaliză cu raze $X$.

Eficacitatea metodei combinate de tăbăcire și ungere a pielii de oaie cu prelucrare mecanică integrată este demonstrată de rezultatele cercetării. Semi-fabricatele de piele obținute prin tehnologia propusă au proprietăți fizice, mecanice și igienice bune (Tabelul 7). 
Table 7: Indicators of sheepskin quality cured by different tanning and greasing methods

Tabelul 7: Indicatori de calitate pentru pieile de oaie tratate prin diferite metode de tăbăcire şi ungere

\begin{tabular}{|c|c|c|c|c|c|c|}
\hline \multirow[b]{2}{*}{$\begin{array}{l}\text { № } \\
\text { Nr. } \\
\text { crt. }\end{array}$} & \multirow[b]{2}{*}{$\begin{array}{l}\text { Indicator } \\
\text { Indicator }\end{array}$} & \multirow[b]{2}{*}{$\begin{array}{l}\text { Reference } \\
\text { documents } \\
\text { Documente de } \\
\text { referinţă }\end{array}$} & \multirow[b]{2}{*}{$\begin{array}{l}\text { Standard } \\
\text { indicators } \\
\text { Indicatori } \\
\text { standard }\end{array}$} & \multicolumn{3}{|c|}{$\begin{array}{l}\text { Tanning and greasing method } \\
\text { Metodă de tăbăcire şi ungere }\end{array}$} \\
\hline & & & & $\begin{array}{l}\text { Tanning and } \\
\text { greasing by } \\
\text { brushing } \\
\text { method with } \\
\text { mechanical } \\
\text { treatment } \\
\text { Tăbăcire şi } \\
\text { ungere prin } \\
\text { periere cu } \\
\text { prelucrare } \\
\text { mecanică }\end{array}$ & $\begin{array}{l}\text { Tanning and } \\
\text { greasing by } \\
\text { brushing } \\
\text { method } \\
\text { without } \\
\text { mechanical } \\
\text { treatment } \\
\text { Tăbăcire şi } \\
\text { ungere prin } \\
\text { periere fără } \\
\text { prelucrare } \\
\text { mecanică }\end{array}$ & $\begin{array}{l}\text { Tanning } \\
\text { and } \\
\text { greasing } \\
\text { by dipping } \\
\text { method } \\
\text { Tăbăcire } \\
\text { şi ungere } \\
\text { prin } \\
\text { imersiune }\end{array}$ \\
\hline 1 & $\begin{array}{c}\text { Cure temperature, }{ }^{\circ} \mathrm{C} \\
\text { Temperatura de contracţie, } \\
{ }^{\circ} \mathrm{C}\end{array}$ & $\begin{array}{c}\text { State Standard } \\
\text { (GOST) 32078-2013 }\end{array}$ & 80 & 83.5 & 74.0 & 83.0 \\
\hline \multirow{6}{*}{2} & $\begin{array}{c}\text { Weight content, } \% \\
\text { Conţinut calculat la greutate, } \\
\%\end{array}$ & & & & & \\
\hline & $\begin{array}{l}\text { Moisture } \\
\text { Umiditate }\end{array}$ & $\begin{array}{l}\text { State Standard } \\
\text { (GOST) 938.1-67 }\end{array}$ & $\leq 14.0$ & 7.3 & 6.9 & 7.6 \\
\hline & $\begin{array}{l}\text { Chromium oxide } \\
\text { Oxid de crom }\end{array}$ & $\begin{array}{c}\text { Russian State } \\
\text { Standard (GOST R) } \\
\text { 53013-2008 }\end{array}$ & $1.5 \div 3.5$ & 2.6 & 3.0 & 2.7 \\
\hline & $\begin{array}{c}\text { Ash } \\
\text { Cenuşă }\end{array}$ & $\begin{array}{l}\text { State Standard } \\
\text { (GOST) 17631-72 }\end{array}$ & $\leq 9.0$ & 6.8 & 8.0 & 7.5 \\
\hline & $\begin{array}{c}\text { Unconnected greasy } \\
\text { substances of leather } \\
\text { Substanţe grase nelegate din } \\
\text { piele }\end{array}$ & $\begin{array}{c}\text { Russian State } \\
\text { Standard (GOST R) } \\
\text { 53018-2008 }\end{array}$ & $\leq 12.0$ & 10.9 & 11.1 & 11.0 \\
\hline & $\begin{array}{c}\text { Unconnected greasy } \\
\text { substances of hair-cover } \\
\text { Substanţe grase nelegate din } \\
\text { învelişul pilos }\end{array}$ & $\begin{array}{c}\text { Russian State } \\
\text { Standard (GOST R) } \\
\text { 53018-2008 }\end{array}$ & $\leq 4.0$ & 3.3 & 3.7 & 3.4 \\
\hline 3 & $\begin{array}{l}\mathrm{pH} \text { of the leather aqueous } \\
\text { extract } \\
\text { pH-ul extractului apos din } \\
\text { piele }\end{array}$ & ГОСТ 53017-2008 & $\geq 3.3$ & 4.8 & 5.05 & 4.01 \\
\hline 4 & $\begin{array}{l}\text { Whole hide rupture load, } \mathrm{H} \\
\text { Sarcina la rupere pentru } \\
\text { pielea întreagă, } H\end{array}$ & $\begin{array}{c}\text { Russian State } \\
\text { Standard (GOST R) } \\
\text { 52957-2008 }\end{array}$ & $\geq 250$ & 421.4 & 406.1 & 395.3 \\
\hline 5 & $\begin{array}{l}\text { Ultimate elongation, \% } \\
\text { Alungirea maximă, \% }\end{array}$ & $\begin{array}{c}\text { Russian State } \\
\text { Standard (GOST R) } \\
\text { 52957-2008 }\end{array}$ & $\geq 30$ & 42.0 & 38.0 & 45.3 \\
\hline 6 & $\begin{array}{l}\text { Moisture-retaining power, \% } \\
\text { Capacitatea de a reţine } \\
\text { umezeala, \% }\end{array}$ & $\begin{array}{l}\text { State Standard } \\
\text { (GOST) 938.24-72 }\end{array}$ & - & 527.2 & 382.9 & 582.3 \\
\hline 7 & $\begin{array}{l}\text { Water penetration capacity, } \\
\qquad \% \\
\text { Capacitatea de pătrundere } \\
\text { a apei, \% }\end{array}$ & $\begin{array}{l}\text { State Standard } \\
\text { (GOST) 938.21-71 }\end{array}$ & - & 25.7 & 20.4 & 19.6 \\
\hline
\end{tabular}




\begin{tabular}{|c|c|c|c|c|c|c|}
\hline \multirow[b]{2}{*}{8} & Vapor capacity, mg/sm² & Russian State & & & & \\
\hline & $\begin{array}{l}\text { Capacitatea de absorbţie a } \\
\text { vaporilor de apă, } \mathrm{mg} / \mathrm{sm}^{2}\end{array}$ & $\begin{array}{l}\text { Standard (GOST R } \\
\text { ISO) } 17229-2009\end{array}$ & - & 15.9 & 13.7 & 12.6 \\
\hline 9 & $\begin{array}{c}\text { Porosity, } \% \\
\text { Porozitate, } \%\end{array}$ & - & - & $62 \div 66$ & $63 \div 67$ & $72 \div 74$ \\
\hline 10 & $\begin{array}{c}\text { Hygroscopicity, \% } \\
\text { Higroscopicitate, \% } \\
\text { Water-yielding capacity, \% }\end{array}$ & - & - & $14 \div 19$ & $14 \div 16$ & $17 \div 20$ \\
\hline 11 & $\begin{array}{c}\text { Capacitate de cedare a } \\
\text { apei, } \%\end{array}$ & - & - & $14 \div 17$ & $13 \div 14$ & $14 \div 18$ \\
\hline 12 & $\begin{array}{l}\text { Adhesive strength of hair } \\
\text { with leather, } H\end{array}$ & - & - & $17 \div 25$ & $21 \div 26$ & $14 \div 25$ \\
\hline & Aderenţa părului la piele, $H$ & & & & & \\
\hline
\end{tabular}

\section{CONCLUSION}

The data obtained confirm acceleration of the chrome-greasy mixture diffusion into the sheepskin structure by cyclic stretching and subsequent compression, resulting in overall pores and capillaries filling with tanning agent due to its geometry change.

The chrome-greasy mixture diffusion was studied by scanning electron microscopy, the results of which indicate that tanning and greasing by brushing method with integrated mechanical treatment ensures even tannin distribution through the leather thickness in 2 hours after ageing.

The suggested combined process of tanning and greasing by brushing method with integrated mechanical treatment significantly reduces processing time of semi-finished sheepskin from 4 hours to $4.5 \mathrm{~min}$., as well as ageing time after tanning and greasing from 4 to 2 hours, and considerably cuts down the water consumption and discharge of toxic wastewater and, thus, minimizes negative environmental impact of leather and fur tanneries.

\section{Acknowledgement}

The work was performed within the framework of the State Target of the Ministry of Education and Science under official registration № 01201462824.

\section{CONCLUZII}

Datele obţinute confirmă accelerarea difuziei amestecului de ungere cu săruri de crom în structura pielii de oaie prin întindere ciclică şi compresiune ulterioară, având ca rezultat umplerea porilor şi a capilarelor cu agent tanant, datorită modificării geometriei structurii.

Difuzia agentului de ungere şi a tanantului cu crom a fost studiată prin microscopie electronică de baleiaj, iar rezultatele indică faptul că metoda de tăbăcire şi ungere prin periere cu prelucrare mecanică integrată asigură distribuţia uniformă a tanantului în grosimea pielii la 2 ore după odihnă.

Procedeul combinat de tăbăcire şi ungere prin periere cu prelucrare mecanică integrată reduce semnificativ timpul de prelucrare a semi-fabricatelor de piele de oaie de la 4 ore la 4,5 min., precum şi timpul de odihnă după tăbăcire şi ungere de la 4 până la 2 ore şi reduce considerabil consumul de apă şi cantitatea de ape uzate toxice eliminate, reducând, prin urmare, şi impactul negativ asupra mediului al tăbăcăriilor care prelucrează piele şi blană.

\section{Mulţumiri}

Studiul s-a desfăşurat în cadrul Obiectivului de Stat al Ministerului Educaţiei şi Ştiinţei cu numărul de înregistrare 01201462824. 


\section{REFERENCES}

1. Strakhov, I.P., Shestakova, I.S., Kutsidi, D.A. et al., Chemistry and leather and fur technology, M.: Legkoprombytizdat, 1985.

2. Bogdanova, I.E., Modern directions of collagen containing waste disposal in tanneries, Leather and Footwear Industry, 2007, 2, 30-31.

3. Dumnov, V.S., The intensification of tanning and post tanning processes through the use of nonaqueous media, Leather and Footwear Industry, 1987, 10, 37-40.

4. Kalashnikova, Y.M., Polomoshnykh, S.P., Shalbuev, D.V., Equipment development for brushing method of tanning and greasing of semi-finished sheepskin, Leather and Footwear Industry, 2013, 3, 32-34.

5. Kalashnikova, Y.M., Polomoshnykh, S.P., Shalbuev, D.V., Technology development for piecework processing of semi-finished sheepskin with an integrated mechanical impact, Leather and Footwear Industry, 2013, 3, 25-27.

6. 'INCA Energy 350’ microanalysis system. User guide. Oxford: Oxford Instruments Analytical, 2004.

Article received/Data primirii articolului: 07.06.2016

Accepted/Acceptat la data: 19.07.2016 